\title{
Soviet Economic Reform: The Longest Road
}

THE STRUGGLE of the command economies to rediscover the market brings to mind the Hungarian joke: "Question: What is communism? Answer: the longest road from capitalism to capitalism." Having spent up to seven decades systematically attempting to eradicate market forces, the Soviet Union and the other socialist countries of Eastern Europe have reversed field in an attempt to revive "the market." The effort reveals much about both systems.

My paper is divided into three general areas. I begin with an overview of the aggregate performance in the socialist countries, particularly the Soviet Union, and compare their performance with that of Western countries. Next I discuss the goals and roadblocks on the road to reform, reform plans for the Soviet Union, and the macroeconomic issues facing socialist countries. I conclude with an assessment of the prospects for reform in the Soviet Union.

\section{Background: Stagnation and Disillusionment}

After decades of rapid growth in output and living standards, the socialist countries began a marked slowdown in economic growth around 1970. Table 1 shows Angus Maddison's estimates of the growth in output and in output per capita in the United States and in the Soviet Union over this century. Soviet growth has been respectable, but was particularly so in the early stages. Table 2 presents estimates, using data prepared by the U.S. Central Intelligence Agency, on total factor productivity in the Soviet Union since 1961. The data suggest that output growth in the Soviet Union has derived primarily from forced-draft 
Table 1. Average Annual Growth of Output and Productivity, Soviet Union and United States, 1900-87, Various Periods

Percent

\begin{tabular}{cccccc}
\hline & \multicolumn{2}{c}{ Gross domestic product } & & \multicolumn{2}{c}{ GDP per capita } \\
\cline { 2 - 3 } \cline { 5 - 6 } Period & United States & Soviet Union & & United States & Soviet Union \\
\hline $1900-13$ & 4.0 & 3.5 & & 1.9 & 1.5 \\
$1913-50$ & 2.8 & 2.7 & & 1.2 & 2.3 \\
$1950-73$ & 3.7 & 5.0 & & 1.4 & 3.6 \\
$1973-87$ & 2.5 & 2.1 & & 1.0 & 1.2 \\
$1900-87$ & 3.2 & 3.3 & & 1.8 & 2.3 \\
\hline
\end{tabular}

Source: Authors' calculations based on Maddison (1989, pp. 113, 128).

Table 2. Average Annual Growth of Output, Inputs, and Productivity, Soviet Union, 1961-85, Various Periods

Percent

\begin{tabular}{ccccc}
\hline & \multirow{2}{*}{$\begin{array}{c}\text { Gross } \\
\text { national }\end{array}$} & $\begin{array}{c}\text { Total factor } \\
\text { productivity }\end{array}$ & Capital & Labor \\
\cline { 4 - 5 } & product & 0.6 & 8.1 & 1.8 \\
$1961-70$ & 5.0 & -1.3 & 7.5 & 1.5 \\
$1971-80$ & 2.7 & -1.0 & 6.2 & 0.7 \\
$1981-85$ & 1.9 & &
\end{tabular}

Source: Kurtzweg (1987, pp. 126-55).

increases in inputs; total factor productivity has shown only modest growth or, in recent years, a decline.

Why did growth slow so dramatically? Analysts suggest numerous causes: a decrease in the growth of inputs (depletion of low-cost resources such as oil, aging of the capital stock, and deterioration of labor discipline); lowered technological change and efficiency (because of numerous planning errors and diversion of $R \& D$ activities to the military); exogenous economic shocks (poor weather and declining prices of exported raw materials); and greater complexity of economic activity (with more products and greater technical complexity). ${ }^{1}$

Numerous analysts, including some Soviet economists, suggest that despite efforts to correct misleading Soviet statistics, Western estimates have overstated Soviet economic growth. Many indications of poor and even deteriorating quality in Soviet industries (both in terms of the

1. See Levine (1982). 
products themselves and in the quality of service) suggest that exaggerated claims of quality improvement bias Soviet price statistics downward and lead to overstated output and hence target attainment. ${ }^{2}$

The declining growth in Soviet output is reinforced by the low share of consumption in GNP and a rising defense and investment burden. The CIA estimates that defense and investment currently absorb around 40 percent of Soviet GNP, up from roughly 34 percent in 1960. By contrast, investment and defense absorb some 25 percent of GNP in the United States. The low Soviet consumption share implies that the per capita GNP figures overstate the level of economic welfare of the population.

In this area, as in assessments of military power, much confusion has been generated by Western estimates that inflate the quality and quantity of Soviet production. According to CIA estimates, the per capita output of the Soviet Union is equal to that of Spain and well above that of Greece. Alternative estimates of per capita output, as calculated by different agencies and by using different measurement concepts, are shown in table 3 . Even the relatively low estimates by the International Comparisons Project (ICP) may give too optimistic an impression of living standards. It would be necessary to make further correctionsadjusting for the large share of output devoted to nonconsumption purposes in defense and investment, for the low quality and lack of availability of goods, and for the frightening deterioration of environmental quality and public health-to obtain an accurate assessment of living standards in socialist countries.

Yet another way to measure living standards-calculating incomes at blackmarket exchange rates-gives a Soviet per capita income of roughly $\$ 225$, surely a lower bound on real incomes. With an overvalued exchange rate and exchange controls, the black market rate reflects the incremental value of imported goods, services, or safe foreign assets to the desperate buyer; it will therefore place an extremely high value on foreign currency. In addition, this rate will tend to underestimate real incomes because of the omission of nontradable goods. Still, while understating per capita income, this figure shows dramatically the uncertainty about the level of

2. The upward bias in the Soviet growth rate is described in Aganbegyan (1988, p. 2). By contrast, as Martin Baily and Robert Gordon showed recently in this journal, there may be significant quality understatement in U.S. national account statistics and a consequent understatement of real economic growth. See Baily and Gordon (1988). 
Table 3. Alternative Estimates of Per Capita GNP, Various Countries, 1987 U.S. dollars

\begin{tabular}{|c|c|c|c|c|}
\hline \multirow[b]{3}{*}{ Country } & \multicolumn{2}{|c|}{$\begin{array}{c}\text { Measured by purchasing- } \\
\text { power parity }\end{array}$} & & \\
\hline & \multirow{2}{*}{$\begin{array}{l}\text { International } \\
\text { Comparison } \\
\text { Project }\end{array}$} & \multirow{2}{*}{$\begin{array}{c}\text { Central } \\
\text { Intelligence } \\
\text { Agency }\end{array}$} & \multicolumn{2}{|c|}{$\begin{array}{l}\text { Measured by } \\
\text { exchange rates }\end{array}$} \\
\hline & & & Official & Market \\
\hline United States & 18,550 & n.a. ${ }^{a}$ & $\ldots{ }^{b}$ & 18,530 \\
\hline West Germany & 13,680 & n.a. ${ }^{a}$ & $\ldots{ }^{b}$ & 14,400 \\
\hline United Kingdom & 12,250 & n.a. ${ }^{a}$ & $\ldots \mathrm{b}$ & 10,420 \\
\hline Spain & 8,520 & n.a. ${ }^{a}$ & $\ldots \mathrm{b}$ & 6,010 \\
\hline Greece & 6,580 & n.a. ${ }^{a}$ & $\ldots \mathrm{b}$ & 4,020 \\
\hline Soviet Union ${ }^{\mathrm{a}}$ & 6,930 & 8,380 & 4,800 & 225 \\
\hline Hungary & 5,780 & 7,910 & 2,240 & n.a. \\
\hline Poland & 4,540 & 6,930 & 1,930 & n.a. \\
\hline East Germany & 9,660 & 11,300 & n.a. & n.a. \\
\hline
\end{tabular}

Sources: Numbers in the first column are estimates of purchasing-power parity (PPP) levels of per capita GNP based upon the International Comparison Project (ICP) estimates. For countries other than the Soviet Union and East Germany, the source is World Bank (1989, table 30, p. 233). For the Soviet Union and East Germany, estimates are rough projections from Summers and Heston (1988). Data on 1985 PPP relatives are applied to 1987 U.S. per capita GNP. Numbers in the second column are from Central Intelligence Agency (1988). Numbers in the third column are from World Bank (1989, table 1, p. 165) except for the Soviet Union, which applies official exchange rate for commercial transactions to CIA estimates of ruble-value GNP. Numbers from the fourth column are from World Bank (1989, table 1), except for the Soviet Union, which applies current black market rate of 13.5 rubles to the dollar.

n.a. Not available.

a. CIA does not provide independent estimates for these countries.

b. These currencies are convertible at market rates and do not have separate official rates.

Soviet real income and the extent to which common estimates may overstate real incomes in socialist countries.

Perhaps the most striking comparison is the performance of East and West Germany. At the end of World War II, the two Germanys had roughly equal levels of productivity and similar industrial structures. ${ }^{3}$ After four decades of capitalism in the West and socialism in the East, productivity in East Germany had fallen to a level estimated between one-third and one-half of that in West Germany. Yet CIA estimates produce the absurd conclusion that the per capita GNP of East Germany is more than 80 percent that of West Germany as estimated by the ICP (see table 3).

Of course, individuals living in socialist countries are unlikely to be persuaded by even the finest Divisia indexes. The simple unavailability of many goods is sufficient to convince consumers of the relative

3. For a discussion of income levels and performance in different parts of Germany, see Wallich (1955). 
attractiveness of the different systems. This point was forcefully put in the comment of the flamboyant president of the Russian republic, Boris Yeltsin, on his voyage to America:

There were . . . shattering experiences of another sort-the supermarkets, for example. When I saw those shelves crammed with hundreds, thousands of cans, cartons, and goods of every possible sort, for the first time I felt quite frankly sick with despair for the Soviet people. That such a potentially superrich country as ours has been brought to a state of such poverty! ${ }^{4}$

\section{The Reform Agenda in Socialist Countries}

Virtually all reform movements in the Soviet Union and Eastern Europe have endorsed a market economy as the ultimate goal of economic reforms. The "Abalkin report," the most comprehensive published analysis of the plans of Soviet economic reformers, states:

The main features of the model of a new economic system [are] . . the use of the market as the main form of coordinating the activities of the participants in production. We have become convinced on the basis of our own experience that there is no worthy alternative to the market mechanism as the method of coordinating the activities and interests of the economic subjects. ${ }^{5}$

Actual reform plans, however, reveal a less than whole-hearted adoption of a market economy. In already-reformed countries like Poland or Hungary, the vast bulk of economic activity is still produced in stateowned firms, and housing prices are closer to zero than to market levels. Radical Reform explicitly advocates continued primary state ownership of energy, defense, transportation, and communications; an unspoken presumption is that the state will continue to own and operate normal government services, education, and health, and may control housing

4. Yeltsin (1990, p. 255) contains a fascinating and almost believable autobiography.

5. Radical Reform (1989, pp. 2-4). The Abalkin report, Radical Economic Reform: Top-Priority and Long-Term Measures (hereafter called Radical Reform), was presented by Leonid Abalkin, Deputy Prime Minister, to the Organizing Committee of the All-Union Conference and Workshop on the Problems of Radical Economic Reform. This proposal was debated at a meeting of the Council of Ministers in November 1989 but was ultimately rejected in favor of a more conservative approach. Among the chief drafters of Radical Reform were Academician Stanislav Shatalin (Secretary of the Economics Division of the Soviet Academy of Sciences and recently appointed to Gorbachev's cabinet) and Professor Yevgeniy Yasin (formerly of TSEMI and currently director of the U.S.S.R. Commission on Economic Reform). 
prices for many years. ${ }^{6}$ A rough guess is that these sectors would comprise only half of GNP in today's Soviet economy.

In addition, popular discussion in the Soviet Union reveals both egregious misconceptions and deep reservations about the consequences of living in a market economy. Hostility toward entrepreneurial activity is profound, and "speculation" is a four-letter word. In her insightful "Letter from Europe," Jane Kramer writes, "The mystique of the market has nothing to do with a marketplace. When Russians talk about the market, they are talking about everything from a new Communism to whatever government of the left or right they happen to admire." 7 Hearing an oxymoron like "free-market Communism" makes one suspect that the market under discussion is closer to the Hegel of political theorists than to the haggle of the Fulton Fish Market.

A final puzzle concerns the scant attention in the reform debates to the implications of a market economy for the distribution of income. Many Westerners are offended by the excesses of income, wealth, and power generated by market rewards. They wonder about a society in which newly minted lawyers get paid more than their professors, in which the rich paint their names on their personal airlines or trade ball players like baseball cards, and in which a financier pays a $\$ 600$ million fine for the investment banker's equivalent of a speeding ticket and has plenty left over. It was just such excesses that led Arthur Okun to give, "Two cheers for the market, but not three."

The vanities of capitalism, however, are the price of a market economy - where wages and prices reflect how well products sell rather than how much some elite thinks they are really worth. Prices and incomes in the market are determined by dollar votes in the marketplace, not ballot votes in elections or bullet votes at the barricades. Have the socialist reformers absorbed the reality of the income distribution in markets in their doctrines?

\section{Roadblocks on the Route to the Market}

To reach the ultimate goal of a market economy, the socialist countries must overcome numerous obstacles that prevent the emergence of

6. Radical Reform (1989, p. 25).

7. $\operatorname{Kramer}(1990$, p. 82$)$. 
market forces. For the Soviet Union, the hurdles are daunting. It is as if, having spent seven decades pouring herbicide on every growing thing in the backyard, they suddenly decide to cultivate a garden. Among the chief difficulties that the Soviet Union faces are the following.

PRICE REFORM AND FREE-MARKET PRICING. Prices of both inputs and outputs are often far from market-determined levels. Perhaps the most thorough study of relative prices in socialist and market economies was made in the international comparison study of incomes, which included Poland but not the Soviet Union. The study found coffee selling in Poland at 9.1 times the U. S. price, personal automobiles at 5.1 times the U. S. price. At the other extreme, rent was 45 percent of U. S. rents for equivalent dwellings, and dentist services were 7 percent of $U$.S. levels. ${ }^{8}$ Anecdotal reports today indicate that apartments in major cities rent for as little as 2 percent to 3 percent of income (perhaps $\$ 1$ or $\$ 2$ a month).

Sooner or later, if prices are to be market-determined, relative prices must be allowed to move to the appropriate levels. One of the important vehicles for introducing realistic prices is to open the economy to international trade. In addition, free markets would involve dramatic changes in the functioning of capital and labor markets; unprofitable firms must be forced to close or allowed to lay off workers or threaten unproductive workers with unemployment. ${ }^{9}$

One measure of the sparseness of markets in the Soviet economy is the number of prices. According to Nikolay P. Shmelev, there are, in the Soviet Union, 25 million distinct prices-upon reflection, an absurdly small number for a modern economy. For example, there are at any time in the United States some 25 million trucking tariffs, as well as some 50 million airline prices (some may wonder whether this is overdoing it a bit). ${ }^{10}$ George Stigler and James Kindahl report that one can get price quotations on 135 million varieties of hot rolled carbon steel sheets. ${ }^{11} \mathrm{~A}$ rough guess would be that the number of products on which one can get

8. Author's calculations based on Kravis, Heston, and Summers (1982, appendix table 6.3).

9. In principle, Soviet firms that lay off workers today have the obligation to find them jobs.

10. Shmelev $(1988$, p. 320). I am told that this figure comes from counting the number of distinct products for which prices are quoted. This example was developed in discussions with Alfred Kahn.

11. See Stigler and Kindahl (1970, p. 5). 
price quotations at any time in the United States must be in the tens of billions.

Although somewhat artificial, this price count reveals an important defect of a command economy: the price system does not operate in many sectors of the economy. Because most capital assets are owned by the state, markets for land, capital goods, and risk-bearing are virtually nonexistent. Socialist ideology has prevented the development of thick markets in financial capital or in housing. Households have as sparse a menu of financial assets as of foodstuffs. There is relatively little differentiation in labor remuneration for different labor skills. In short, Soviet prices are doing neither the gross tuning nor the fine tuning that they do in an advanced market economy.

HARD BUDGET CONSTRAINTS. Soviet enterprises operate with "soft budget constraints," a term signifying that operating losses lead to more bank credits rather than to bankruptcies. In planned economies that have turned to price instead of quantity rationing, such as Hungary, firms engage in endless haggling with the central authorities about taxes or credit conditions. ${ }^{12}$ Of course, the United States is no stranger to the peril of soft budget constraints: its taxpayers will be paying hundreds of billions in extra taxes over the next few years because of the lack of budget discipline in the federal deposit insurance system.

STABILIZATION. Some of the socialist economies have growing problems of large budget deficits and repressed inflation. Developing a full market economy will require achieving fiscal balance, a topic addressed in the next section. It is likely that stabilization will require budget reforms, such as the substitution of income-tested transfer payments for heavily subsidized food and housing prices. Imposing hard budget constraints on Soviet enterprises will also involve reforming the free granting of credits or subsidies to unprofitable enterprises.

PRIVATIZATION OF INDIVIDUAL SEctors. In the United States and other market economies, output is primarily produced in private firms. Despite the alarums about the growth of the public sector in the United States, only 3 percent of U.S. GNP is produced in the federal sector and 10 percent in all levels of government and government enterprises. In socialist countries, the analogous figure is probably between 80 percent and 90 percent. Even today, after the market reforms

12. See Aven (1990). 
introduced in Poland at the beginning of 1990, somewhere around 80 percent of Polish GNP is produced in government enterprises. ${ }^{13}$ At some point, in a gradual or abrupt way, the actual decisions about buying, selling, pricing, producing, borrowing, and lending must be made on a decentralized basis by private agents.

COMPETITION. One underrated element in economic reform is introducing competition into markets. Centrally planned economies have pursued Engels's view that socialism is "one giant factory." Monopoly is pervasive. This industrial structure must be replaced with one with workable competition-say, three or more independent firms and exposure to international competition.

institutions of the market. Above all, the Soviet economy lacks the institutions and infrastructure that are required to operate a market economy. These include accountants and accounting standards, lawyers and contract laws, market research and sales people, banking regulations and bankers, a list emphasizing that the written rules-the decrees that proliferate in socialist economies-may be much less important than the human capital embodied in experienced people who understand and operate the institutions of the market. Property rights must be completely redefined.

In addition, people will have to adopt the attitudes of the market. As Professor Yevgeniy Yasin puts it:

The market is a social institution that requires certain rules of conduct from people. "Economic man" - with his inherent rational conduct, strongly motivated by considerations of personal profit, calculating, driven by the spirit of enterprise, ready to take risks and assume personal responsibility for his actions-should be given public recognition.

The model that is currently prevalent in the Soviet Union is of "administrative man," to use H. Simon's term. He is typically used to submission and giving orders, to living in a structure of prevailing vertical links. In his subordinate role, he is likely to show pro forma obedience, turning to actions without rules. Lower strata of the hierarchy expect the upper strata to protect them in most relations with the outside world and recognize social paternalism as the norm. ${ }^{14}$

Table 4 provides a summary list of the obstacles on the road to a fully developed market economy. The list is long, and introducing any one

13. Economic Report of the President, February 1990, table C-8. For socialist countries, private conversations. We might wonder whether the market-oriented Poles have inadvertently invented a form of market socialism quite unlike that envisioned by Oskar Lange and others.

14. See Yasin (1990, p. 16), with slight changes in translation. 
Table 4. Roadblocks to Economic Reform

1. Price reform and free-market pricing

Eliminate central allocation and rationing

Raise prices on necessities

Free competitive sectors

Privatize and regulate natural monopolies

2. International

Remove quantitative restrictions and substitute tariffs

Align different exchange rates

Allow foreign investment

Convertibility of currency

3. Capital market changes

Free interest rates

Commercial (retail) banking separated from central bank

Control money supply

4. Labor markets

Free firms to lay off workers

Unemployment insurance and welfare reforms

Housing reforms for mobility

\section{Hard budget constraints}

Reform accounting

Profit constraints

Credit constraints

End tax and regulatory haggling

\section{Stabilization}

Reduce budget deficit

Raise interest rates

Anti-inflation policies (tax-based incomes policies, foreign competition)

7. Budget reform

Remove redistributional pricing and substitute income-tested transfers

Remove subsidies to failing firms

8. Decentralize economic decisions Allow private property Separate firms from government Privatize firms and production

\section{Competition}

Break up monopolistic state firms Antitrust laws and regulation Entry of foreign firms

Encourage small enterprises

10. Institutions of the market

Contract and bankruptcy law

Train managers

Nurture homo economicus

Change anti-market sentiments

measure will encounter formidable institutional and political obstacles. Moreover, a simple catalogue does not capture the interconnection of the different obstacles. For example, hard budget constraints are a prerequisite to allowing realistic cost calculations for free-market pricing, to bank reform, to reducing the government deficit, to reducing enterprise subsidies in the budget reform, to efficient private decisionmaking, and to nurturing homo economicus and the spirit of enterprise.

\section{Sequencing the Transition: the Three Approaches}

There is little disagreement among reformers about the need to move quickly to a market economy. The critical question is the sequencing 
and speed of the transition. Socialist economies have so many problems, and they are so interconnected, that reformers are unsure where to begin. Should they start with the budget, with privatization, with property reforms, with capital markets, with reducing subsidies, with freeing the ruble, or what? Should reform begin with budget reform so as to prevent a price-wage-price spiral when prices are decontrolled? Or should price inflation and wage controls be used to reduce real aggregate demand? Should there be a first step to get prices close to the market before letting prices go? Or is it hopeless to try to guess the "right" market price? Should prices be decontrolled now, so that incentives to production are enhanced? Or should the monopolies be broken up first to prevent the exercise of monopoly power? Should governments avoid political peril by postponing an increase in the prices of necessities (housing, food, and energy)? If so, will the resulting queues and inefficiencies restrict labor mobility, impede adjustments, and reduce incentives to work and bear risk? This list could be multiplied indefinitely.

The reform debate is currently divided into three camps: the radical (sometimes called the "big bang") approach, which would introduce the market reforms simultaneously; the step-by-step approach, which would phase in reforms gradually; and the conservative approach, which advocates moving cautiously if at all toward a market.

BIG BANG A PPROACH. The approach currently being tested in Poland is the simultaneous introduction of numerous pro-market measures. The Polish authorities are removing barriers to entry and exit in most markets, decontrolling many prices, liberalizing foreign trade, reducing subsidies, and stabilizing the economy. The example most often pointed to as a historical precedent is the 1948 monetary reform in West Germany..$^{15}$ It should be emphasized, however, that virtually no privatization or demonopolization has yet occurred in Poland, and some observers

15. As a matter of historical accuracy, however, it should be noted that there are two big differences between the German reforms of 1948 and the current situation in socialist countries. First, although Germany had been subjected to considerable central rationing and price controls, which began in 1935, many of the institutions of the market remained in place-banks, large private corporations, accounting systems, and, most important, human capital in the market skills and knowledge of the functioning of markets. Second, the movement to a full market was phased in over an extended period, with many prices controlled and the currency partially inconvertible until the 1950s. This episode is described in detail in Wallich (1955). 
believe that this may be responsible for part of the steep price increases in early 1990 .

STAGED APPROACH. The approach currently favored by economic reformers in the Soviet Union is the step-by-step or gradual introduction of economic reforms. The Abalkin plan described in Radical Reform espouses this approach, which envisages three stages over six to ten years. The first stage is to create the legal framework (law on property, law on bankruptcy, and so forth) in which markets can grow. A second stage would take a number of substantive reforms (reduce the budget deficit, reform prices, close unprofitable enterprises, and reform credit). The third stage would allow a significant amount of market determination of prices and introduce foreign competition and partial ruble convertibility.

CONSERVATIVE APPROACH. In late 1989, different approaches to reform were debated in the U.S.S.R. Council of Ministers. The Abalkin plan was criticized, and a substitute introduced by Prime Minister Nikolay Ryzhkov was adopted. The conservative plan had three elements: stabilize the economy by balancing the state budget, retighten central controls in wage and price determination, and reallocate resources from defense and investment to consumer goods. ${ }^{16}$ It is noteworthy that the most painful and politically sensitive step-price reform-has been repeatedly postponed during perestroika. The price of bread is scheduled to increase in July 1990, and some other goods may see price increases in January 1991, but a thorough price reform is still a distant goal.

In the spring of 1990, after Gorbachev was elevated to his position as president with strong executive powers, there was a great deal of speculation about whether he would use his powers to introduce a big bang, or at least to move quickly with the first phase of the step-by-step reform advocated by his close advisers. While it is difficult to read the tea leaves, it appears that the big bang approach has been rejected and that the first steps of reform will be introduced in the summer of 1990. It seems likely that the steps will take the form of continued property reforms and liberalization of the rules of enterprise.

The most treacherous steps involve "price reform," which is the euphemism for raising consumer prices. Given the perils of speculative

16. See the discussion in Ofer $(1990$, p. 3). 
hoarding, it would clearly be foolish to announce a major price reform far in advance. On the other hand, imposing reforms without popular support invites strikes, dissension, and loss of confidence in the government.

\section{Reflections on the Three Strategies}

In weighing the relative attractiveness of the three approaches, the experience of economic reforms in other countries can usefully be applied. ${ }^{17}$ To begin with, it is clear that if by a big bang we mean moving immediately to a genuine market economy, this is simply impossible. As table 4 shows, the steps necessary to create a genuine market economy require a great deal of fundamental restructuring, some of which (such as development of capital markets, education, fostering the spirit of enterprise, and full privatization of state enterprises) will require years or decades to accomplish.

What is usually meant by a big bang is in fact a simultaneous partial liberalization (such as occurred in Poland). This would involve freeing prices in a substantial part of the economy (most of the tradable sector along with small enterprises) while opening the economy to foreign trade. Such an approach would seem feasible where a country is relatively small and open, where the public is hostile to a socialism imposed by a foreign power, and where there is some experience or at least memory of markets. These criteria would apply in most of the countries of Eastern Europe, particularly Poland, East Germany, Hungary, and Czechoslovakia. Obviously, a big bang could be used for isolated sectors within a largely capitalist economy (as in lifting government regulation of the airlines in the United States or in privatizing nationalized enterprises in Japan and the United Kingdom).

But is the big bang appropriate for the Soviet Union? However appealing this approach is to frustrated reformers, I am skeptical about its acceptability or advisability for the Soviet Union as of mid-1990. The Soviet economy is large, closed, and extremely hierarchical. The obstacles to reform are higher and deeper in the Soviet Union than in other Eastern European countries. Unlike other socialist countries, the Soviet yen for the market is primarily confined to mathematical economists.

17. Particularly useful are the lessons from development economics. A thoughtful analysis is presented in Ranis (1990). 
While the system is barely creaking along today, it could be worse. The short-term gains from a big bang are limited, while the risks include the possibility of a complete breakdown of the economy, mass unemployment, political unrest, widespread economic distress, breakdowns in the distribution chain, hunger, or famine.

If the Soviet leaders choose instead a step-by-step approach, are there any lessons about the best sequence for reforms? With one exception, the sequence envisioned by the Abalkin plan discussed above seems on the whole a reasonable plan. The Abalkin plan begins by fostering the institutions of the market, then moves on to stabilize the economy and align relative prices, and finally to free markets. My only reservation about the plan is that it may place too little emphasis on macroeconomic stabilization efforts needed to reduce the queues and prevent serious macroeconomic imbalances. This important issue will be addressed in greater detail in the next section.

Although there are strong reasons for favoring the step-by-step approach as the only realistic path for the Soviet Union, one important danger must be acknowledged-that the transition will be phased in so slowly as effectively to stall reform. This is, indeed, a reasonable description of the progress of the Gorbachev reforms through May 1990; they have almost surely exacerbated the economic problems of the Soviet economy. It appears that the liberalization of the economy after 1985 allowed firms to raise wages above planned levels with the result that incomes outran production. As the shortages grew more severe, the government recontrolled prices and tightened central control; the extent of rationing is greater now than at any time since World War II.

A defender of the recontrol might cite Lenin's dictum that progress requires two steps forward and one step backward. Without great vigilance, this easily becomes two steps backward for every one step forward-and thwarts reform altogether.

These reflections raise an intriguing possibility, a Murphy's Law of Reforms. This holds that reforming an internally consistent economic system makes things get worse before they get better. Any single reform (or perhaps any limited set of pro-market reforms) will aggravate the difficulties of a command economy. The reason is that socialist states have evolved a set of rules, incentives, and expectations designed to optimize economic performance within the confines of a command 
economy. Changing any rule, however sensible in the framework of a market economy, may lead to distortions that worsen performance in the partially reformed command economy.

In other words, within the framework of the command economy, planners, consumers, and enterprises adapt their behavior to optimize their objectives. For a given set of institutions, planners devise incentives that lead economic agents to perform relatively efficiently. If the planners are competent, they achieve a local optimum subject to the fundamental ideological and political constraints of socialism. Removing one or two of the constraints will defeat some of the rules that have produced the local socialist optimum.

A biological metaphor that captures the adaptive nature of economic systems comes to mind. No one doubts that a fish swims better than a dog. But dogs do swim in their own funny way. And replacing a dog's legs with a fish tail, in a step-by-step reform of canine navigation, would quickly produce one sad pup.

\section{Economic Stabilization}

A central task of managing economic reform will be to maintain macroeconomic stability during the transition. On the whole, this is a new topic for socialist reformers. Until recently, socialist macroeconomics referred to economic planning and ensuring plan fulfillment. Unemployment was nonexistent in principle and, for the most part, in fact. Inflation of official prices was contained by leaving official prices fixed for long periods. When aggregate demand became excessive, these economies suffered "repressed inflation," a syndrome in which too-low prices result in high black market prices, long lines for goods, and forced saving. What Western economists call "macroeconomics," in the sense of the determinants of national income and output in the short run, is not yet a discipline among Soviet economists.

As socialist economies begin to liberalize their prices and allow enterprises to fire workers, the familiar symptoms of a market economy emerge. People lose their jobs, liberalized prices (in both the state and private sectors) begin to rise, and the populace complains about unemployment and inflation. At this point the Soviet Union will come up 
against the need for stabilization policy as the nation makes the transition to the market. ${ }^{18}$

The task of short-run macroeconomic policy is to ensure that the economy is in overall or aggregate balance. Using fiscal and monetary policies, policymakers aim for internal balance, which signifies that nominal aggregate demand is close to the potential output of the economy at the existing price level. ${ }^{19}$ Internal balance involves both a level (or stock) and a growth (or flow) requirement. The level requirement is that desired spending in the economy (by households, enterprises, and the government) be close to the current-price value of output; the growth requirement is that total incomes and total spending grow at about the same rate as potential output. If desired spending in the economy greatly exceeds the current-price value of potential output, then the economy will tend toward repressed or open inflation.

By these criteria, the Soviet economy currently has many serious macroeconomic problems. To begin with, the government budget is seriously out of equilibrium, resulting in flow imbalance. The budget deficit has grown from 2 percent of GNP in the early 1980s to around 11 percent of GNP in 1989. There is also stock imbalance, with the government debt at around 44 percent of GNP and growing. In a market economy, such a large deficit and debt could be mopped up by borrowing; in the Soviet economy, however, the absence of marketable securities means that the deficit is effectively monetized. The large quasi-monetary imbalance is sometimes referred to as a "ruble overhang," which denotes a large accumulation of undesired holdings of money and other liquid assets by households and enterprises.

The easiest way to determine the size of the ruble overhang is to calculate the ratio of household liquid assets to household income. Based on fragmentary data, this ratio is estimated to have risen from around 0.6 in the $1970 \mathrm{~s}$ (when there was little ruble overhang) to around 0.95 in 1989. ${ }^{20}$ Applying the crude quantity theory suggests that prices would

18. A discussion of the issues from a Soviet perspective is contained in Kagalovsky and Khandruyev (1990). The authors are directors of research at, respectively, the State Committee on Construction and the State Bank of the Soviet Union. Many of the macroeconomic issues are addressed in Ofer (1990).

19. Macroeconomic balance also entails external balance, in which the current account and capital flows are in balance. I concentrate on issues of internal balance as these seem more pressing for the Soviet Union in the near term.

20. See Ofer (1990, table 2, pp. 36-37). 
have to rise more than 50 percent to extinguish the overhang. ${ }^{21}$ Unless neutralized, the ruble overhang will produce a sharp, one-time rise in prices when prices are decontrolled.

An understandable response to the peril of a large and growing ruble overhang_indeed a policy followed by the Soviet government since late 1989-is to clamp down tighter on prices. But that strategy works no better than tightening the lid on an overheated pot. It is not possible for centrally planned economies to avoid difficulties from excessive demand by controlling prices. In an economy with price controls-whether the Soviet Union in 1990 or the United States in 1944-the result of excess demand is shortages, long lines, and an increasingly inefficient distribution system. One result of the German decontrol of 1948 or of the Polish decontrol of 1990 is that goods magically appear in the shops. (The problem is that they are too expensive to buy.) The inefficiencies of repressed inflation are yet another reason why it is imperative for East European economies to get and retain control of their fiscal and monetary policies.

Figure 1 illustrates the impact of a growing ruble overhang. At an initial equilibrium, with aggregate demand of $A D$ and aggregate supply of $A S$, prices are fixed below market-clearing levels. State firms are producing at point $a$, and the excess of desired spending over output is given by the segment $a c$. The actual outcome depends upon the rationing mechanism, but we can simplify by assuming that goods are rationed by queuing, that the length of the queue adjusts to balance supply and demand, and that the goods obtained by queuing are then resold at black market prices. ${ }^{22}$ Under these assumptions, point $b$ in figure 1 is the "true" price as measured either by the black market prices or by the

21. The reasoning based on the quantity theory runs as follows. Assume that household liquid assets (which are primarily currency and savings accounts) are the only "outside money." That is, they are the only nominally denominated exogenous variable in the economy. Further suppose that the economy was in macroeconomic equilibrium with a asset-income ratio of 0.60 and that the asset-income ratio rose to 0.95 today. Then, if the only factor out of equilibrium were the ruble overhang, prices would have to rise by a factor of $0.95 / 0.60$, or slightly over 50 percent, to reestablish the earlier desired assetincome ratio.

22. An illustration of such a mechanism is provided in the paper by David Lipton and Jeffrey Sachs in this issue. Note that the assumption concerning queuing will lead to a relatively benign outcome. If some of the scarce goods are siphoned off to the nomenclatura or to low-priority users, the shortages will be relatively worse. 
Figure 1. Impact of Ruble Overhang: Increase of Demand from Deficit

\section{Price level}

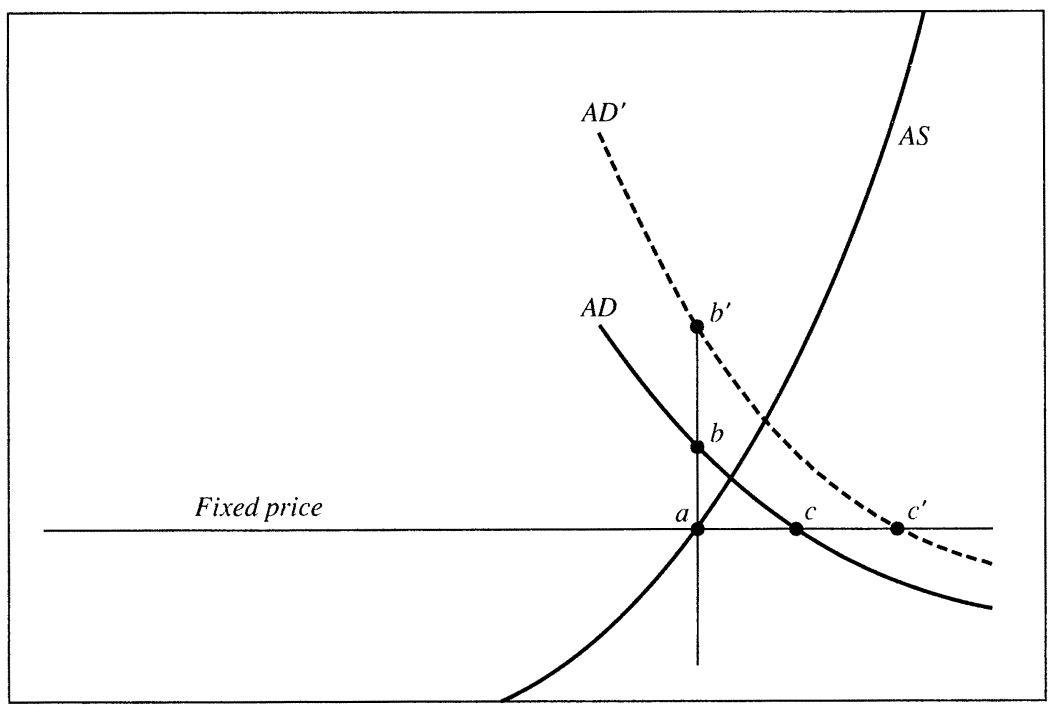

National output

shadow prices of output including costs of waiting, bribing, and using influence.

As the budget deficit increases the ruble overhang, aggregate demand rises to $A D^{\prime}$. Because prices are fixed, there is of course no official inflation. But the excess demand gets worse as the amount people wish to buy at the official price level increases while the supply is unchanged. The ex ante shortage-which is the difference between aggregate demand and supply at official prices-grows to $a c^{\prime}$. The black market prices or shadow prices rise to $b^{\prime}$.

What is the result? The shelves get barer and barer; lines get longer and longer; the stores have nothing to offer but rusty tins and rotten cauliflower; the street price of hard currency diverges even further from the official rate; the free prices in farmers' stalls rise sharply; consumers must spend more and more time foraging for goods; consumers buy goods they don't need as a desperate form of saving; people from highshortage regions take long trips to the cities and other low-shortage 
regions, exacerbating regional tensions; those who have or sell goods at the high social shadow prices are vilified and accused of profiteering; economic planners are driven to ration basic goods-like soap, meat, and sugar-in effect replacing the devalued ruble with a multitude of local and commodity-specific currencies in the form of rationing coupons. In essence, by an extension of Gresham's law, overvalued things (rubles) are driving out undervalued things (goods).

It is clear that, whatever the pace of reforms, the Soviet government must restore macroeconomic balance. One approach often discussed is to attack the problem by soaking up the ruble overhang. Some call for a "monetary reform," which in effect confiscates some of the ruble overhang by introducing a new currency at unfavorable rates to existing rubleholders. Another approach is to introduce a "parallel currency," perhaps one convertible into hard currencies. Yet a third approach, similar to that taken in Poland at the beginning of 1990, would be to let prices rise sharply so that the real value of ruble holdings declines to the level desired by ruble owners.

In fact, these ideas will at best solve the stock, or level, problem and leave the flow, or growth, problem of a large budget deficit untouched. If the budget deficit continues at high levels, aggregate demand will grow rapidly, and the "inflationary gap" between desired spending at existing prices and real output will continue to widen, producing continued repressed or open inflation. A durable solution to the macroeconomic problem of excess demand will require a reduction in the budget deficit.

This point leads to an important linkage between macroeconomic and structural policies. Almost all observers of the Soviet economy believe that the structure of the budget is inefficient and undesirable. There are substantial subsidies to food and agriculture (amounting to 24 percent of the Soviet budget, or 12 percent of GNP) and to unprofitable enterprises (about 10 percent of the budget, or 5 percent of GNP). Defense probably absorbs 20 percent to 30 percent of the budget, although the exact size of the Soviet defense establishment at realistic prices is probably known by no one ${ }^{23} \mathrm{~A}$ promising approach to reform, therefore, is to restructure the budget to ensure macroeconomic stability, to align relative prices with social priorities, and to make room for growth in private consumption.

23. Ofer (1990, table 1, p. 35); CIA (1988, p. 19). 
Some Soviet economists have recommended creating a two-level banking system to help limit money growth as a means of controlling inflation. Without doubt, creating a market-oriented banking system will be a vital part of a reformed Soviet economy. But it seems certain that there is today no way that monetary policy can operate to control spending independently of fiscal policy. There are virtually no retail banks, no credit market instruments, and no variable-price or variableyield assets. The total value of equity-like "stocks" is around 0.02 percent of national income. Mortgages are unheard of. The chief household nonmonetary financial assets are savings accounts and lottery bonds, both of which are virtually perfect substitutes for money.

Because of the structure of financial markets, most of the government deficit is effectively monetized. Even with a broader menu of assets, it is difficult to identify components of spending that are interest sensitive. For example, without hard budget constraints, why would firms tighten their belts in response to interest or credit signals? For all these reasons, monetary policy is not an independent macroeconomic policy instrument at this time. In the near term, therefore, the task of controlling excessive aggregate demand will fall largely on fiscal policy.

In studying the performance of socialist economies, a Western macroeconomist cannot fail to notice the disastrous side effects of producers operating in a sellers' market. Until now, socialist enterprises have had no fear of depressions or idled capacity. The symptoms of high-pressure economies have been queues for any reasonably high-quality good, sellers' rationing, deterioration of product quality and variety, poor service, lack of labor discipline, and low rates of innovation.

The experience of Eastern Europe leads one to wonder whether Arthur Okun overestimated the advantages of a high-pressure economy in promoting many economic objectives when he wrote in 1973, "The greater diffusion of opportunity and of upward mobility in a fullutilization economy is a vital social benefit; and that benefit helps to explain why the pursuit of full employment is an integral part of a liberal's creed." 24

The conventional worry about Okun's emphasis on a high-pressure economy has been the dangers of high inflation. ${ }^{25}$ There may in addition

24. Okun (1973, pp. 246).

25. See, for example, the discussion of Okun's position by William Fellner and Alan Greenspan that follows his article. 
be subtler macroeconomic costs involving lowered overall market discipline. The unhappy lesson of Eastern Europe is that super-full employment and chronic full utilization of capacity seem less effective than unemployment and excess capacity in promoting attention to quality and variety of product, product and process innovation, adjustments to structural change, and a general sense of market discipline among workers and managers.

In sum, there will be no substitute for governmental budget discipline-reducing the budget deficit and perhaps mopping up the ruble overhang-in reducing the pandemic and growing shortages and excess demand in the Soviet economy today. Although fiscal austerity may have unpopular elements, it can be sweetened if the fiscal reforms involve reducing defense spending and uneconomic subsidies. However, the primary attraction of a tight fiscal policy will be to restore value to the currency and to reduce inefficient nonmonetary rationing devices like queues, coupon rationing, and bribery.

\section{Overall Assessment}

At the end of the day, how likely are the Soviet reform efforts to succeed? Before voicing certain gloomy thoughts about the future of economic reform, I must begin by applauding the immeasurable contribution that the Gorbachev political reforms have made to freedom in socialist countries and peace in the entire world. Even if he were to step down today, he would surely stand among the great leaders of the modern world.

On the economic front, however, the road has proven rockier. We should place little confidence in prognostications about the economies of Eastern Europe. Nonetheless, it is hard to have high hopes for a rapid turnaround in economic growth for the Soviet Union.

To begin with, economic reform has been long on rhetoric and short on substance. The small steps toward liberalization since 1985 have mainly increased income growth and have had little impact on output. Shortages have increased, rationing is widespread, and relative prices are probably more distorted than they were in 1985 . No substantial successes have been achieved in removing the roadblocks to reform listed in table 4. Moreover, while the political changes won by Gorbachev 
have augmented his executive powers, Soviet reformers appear deeply divided on the sequence of reforms, and no coherent reform plan has emerged. Both stabilization policy and price liberalization seem further away today than they have been since 1985 .

In addition, while political sentiments are difficult to assess, the strong pro-market sentiments found in many Eastern European countriesparticularly Poland and Hungary-have not become widespread in the Soviet Union. Recent polls put confidence in the Communist party and the KGB above that in the State Commission on Prices or the Ministry of Retail Trade. The growth of political democracy, with its traditional antipathy to taxes or increases in the prices of basic necessities, augurs poorly for reaching a political consensus in favor of a dramatic increase in consumer goods prices. Moreover, in the face of continued struggles among nationalities, political energies may be siphoned off into keeping Lithuania, Russia, and other republics in line instead of pushing through unpopular reforms. It may well be necessary to have a regime change and a repudiation of communist government in the Soviet Union before the transition to the market can be completed.

Most important, as the economic experience of both the advanced industrial countries and the third world amply demonstrate, successful reform programs leading to rapid economic growth are the exception rather than the rule. Latin America is littered with failed reform programs. Hungary, which has more than two decades of reform behind her, has yet to find a way out of the swamp of central planning. The socialist countries of Eastern Europe have undertaken numerous reforms over the past four decades, yet none has yet produced a vibrant and rapidly growing economy. Perhaps the Poles have discovered the magic potion in their 1990 experiment, but it surely is off to a rocky start. Even those successful reform efforts in East Asia have taken many years to bear fruit.

All this is not an argument for halting the process of economic reform. Fitful capitalism may be preferred to stagnant socialism, and the reform process must start somewhere. I end on an optimistic note by concluding that if the advocates of the market convince a skeptical public, overcome their conservative protagonists, design their reforms wisely, choose the correct sequence of measures, eliminate the budget deficit, have good luck with harvests, survive the political turmoil of a disintegrating empire, and persist for a decade-with all these, they have a ghost of a chance. 


\section{Comments and Discussion}

Ed A. Hewett: There is a lot to talk about in this paper and a lot to talk about in the reform. I will focus on William Nordhaus's general conclusion that reform should happen in stages. I used to believe in reforms by stages, but not anymore. I have seen too many slow reforms fail to believe in them. I offer my comments with considerable humility because no one really knows right now how to create a market economy, and in the Soviet Union special problems make it, in some ways, doubly difficult.

The first point I would make is that Nordhaus overestimates the psychological impediments to the big bang, at least in the Soviet Union. To be sure, he makes a number of statements that reflect conventional wisdom on the Soviet Union. Soviets don't understand markets. Speculation is a four-letter word. The "yen" - his pun, not mine-for the market is confined to mathematical economists. There is hostility to entrepreneurial activity.

Let us discuss each of these propositions, first of all, the yen for the market and how low it is in the Soviet Union. On January 1, 1988, 8,000 cooperatives in the Soviet Union employed 88,000 people. Today, about 4.5 million people work in more than 200,000 cooperatives. In the last six months of 1989, a million people joined the rolls of coops, and about 50,000 cooperatives were founded. Coops are thriving although economic policy toward them is restrictive, and the social environment is hostile and, in some cases, physically threatening to cooperators. So I am not convinced that the yen for markets is quite as constrained as many people think it is, although I admit that that still remains to be proven.

Indeed, "speculation" is a four-letter word in the Soviet Union, even among the mathematical economists who yearn for economic reform. 
They can talk as eloquently against speculators as they can for economic reform. On the other hand, I think a good sales pitch-it would have to be by Gorbachev-could make the point that the introduction of a fullblooded market in the Soviet Union would reduce the opportunities for speculators, not increase them. Those who have visited the Soviet Union know what I am talking about. This immensely complex bureaucratic system provides innumerable opportunities to get hold of scarce supplies and sell them for exorbitant prices. In a market with free prices, those opportunities would disappear.

Is there hostility toward entrepreneurial activity in the Soviet Union? I suppose so, but I think many people underestimate the entrepreneurial capabilities of Soviet managers even now. Anyone who has spent some time looking at what it is like to operate an enterprise in the Soviet Union must come away with admiration for what Soviet managers do in conditions that we could best understand by thinking about the worst days of World War II in the U.S. economy. These are people who, on a daily basis, do not know what inputs will show up, what their quality will be, how many workers they will have. And yet, somehow the factories manage to keep going. They can deal with input uncertainties in a way that most Harvard MBAs would find impossible. What they cannot do, and what they are going to have to learn to do, is to deal with uncertainties on the output side, both in price and in finding customers. I happen to believe that they have more capabilities to learn than many people think they do.

Finally, what of the proposition that the Soviets don't understand markets? I dare say they don't. Not many people do. In a referendum in the United States on the question "Do you support capitalism?" surely 98 percent would say yes. If, on the other hand, someone wrote down the way our system works and laid out precisely all the consequences of it and took a referendum, I would not want to be fighting for the plus side of that proposition because I suspect it might lose. I remember, for example, during the 1973 oil shock in the United States, how many people in line at one gas station told a reporter that they would rather wait in line than have prices go up to their equilibrium level.

In thinking about how to create markets-something no one knows a great deal about-we have emphasized too much the need for a majority of the population to be ready to accept markets before they can be introduced. I think, on the contrary, you will never get the majority of 
the population to accept a market before the fact. After they have lived in a market for a while, however, they might learn to love it.

One point Nordhaus makes is quite legitimate and important: the more one thinks about creating a market economy the more one comes to understand the complex web of institutions, of practices, and of welltrained people necessary to make a market work. The underpinnings do not exist in the Soviet Union. There is, for example, no commercial banking system in the Soviet Union. The people who work in commercial banking are really tellers with green eyeshades who pass what they call money back and forth. Similar gaps exist throughout the system.

On the other hand, although I do not know for sure how one develops markets, I am pretty sure one does not do it by simply debating laws in Moscow or sending people to school. Markets develop by throwing people into them. The government can then offer schooling to those who want to learn more. For Soviet enterprise managers-these people in whom I have more faith than Nordhaus does-you have to hit them over the head and get their attention, and then let them start learning about how to operate in a market.

I also think Nordhaus underestimates the cost of going slow. One point that he makes is that the big bang could bring a collapse in the Soviet economy. I suppose it might, but unless something happens quickly, the economy is going to collapse anyway.

Since the middle of last year, industrial output has started to slow down at an accelerating pace. Even official statistics for industrial output the first three months of this year show about a 1 percent decline, and those statistics probably have a 5-6 percent hidden inflation built into them. Every month, economic activity is falling, and at an increasing rate. Other indicators suggest that now shortages are feeding upon each other.

The shortages are particularly dangerous in a hyper-monopolized system. Approximately one-third of important industrial products in the Soviet Union are produced by only one enterprise. If that enterprise sneezes, the economy catches cold. To give just one example, only one enterprise in the Soviet Union produces electric locomotives. It produced only 75 percent of its goal in 1989. Why? Because only one enterprise produces the engine for the locomotives, and it produced only 75 percent of its goal. Why? Because it could not get parts because the transportation system is messed up. 
That is the situation they are in now. I was in Moscow last month. I can tell you that many people in the government now are near a state of panic over the economy, which, from my point of view, is precisely where they should be.

If Murphy's Law of Reforms is that anything you do will make things worse, I would offer one amendment: if you do nothing, things will be worse yet. But I would also make the more general observation that the past five years of Soviet reform offer living proof that partial reforms make things worse. We knew that already, which is why I am interested in a big bang and not in going slow.

The final point I would make about going slow is that slow reforms will probably never get anywhere, a point Nordhaus touches on in passing. For example, if you keep the 30-odd branch ministries that are now de facto the owners of enterprises in the Soviet Union, they will, on the first day of a reform, gut any reform measures that they are asked to implement.

For example, we all agree that a reform that works well is going to involve privatization-rather quick privatization. Who is going to manage the privatization? In the Soviet Union the temptation is going to be to let the ministries do it, that is, let the ministries divest themselves of their own enterprises. If you believe that they will do that, I have got a bridge to sell you. Soviet ministries have proven many times, over many years, that they are adept at renaming what they are doing in order to make Soviet leaders happy, while doing just the contrary of what Soviet leaders want them to do.

Another problem with partial reforms is that it is necessary to begin by giving subsidies to enterprises, with a schedule for how those subsidies will decline over time. Because of the budget-balance problem, it will be necessary to cut subsidies the first day, and then to reduce them quickly. Winners and losers must be chosen ahead of time, requiring a tremendous amount of information about which enterprises will survive the earthquake in the price system.

But if it is possible to predict winners and losers at that point, an economic reform is unnecessary. One can simply go ahead and run enterprises directly from Moscow. The fact of the matter is that it is impossible to specify the subsidy schedule with confidence. Enterprises, knowing the subsidy schedule is a best guess, will support the reform, but argue that their case should be an exception. In the resulting battle 
for exceptions, enterprises will usually win. The likely outcome within a few years is that subsidies are no lower than they were before because every enterprise is an exception to the reform.

Clearly, a quick reform will require doing many things at the same time. Nordhaus's table 4 is an excellent list of what needs to be done, one of the best I have encountered.

Because it will not be possible to do everything in table 4, it will be necessary to set priorities. I would put several items on my top priority list. At the beginning, prices should be revised and then freed up as quickly as possible. This should be done in an environment of tight money, where measures have been taken to reduce the monetary overhang. There are several ways to do that, and Nordhaus goes through them.

A simple but effective commercial banking system should be in place. Nordhaus is quite right in pointing out that Soviet economists are infatuated with rather sophisticated financial instruments and institutions, and they are not paying enough attention to the need for a simple banking system.

Government policy should be fiercely pro-competitive, which means not only breaking up the large enterprises and privatizing them but, at the same time, encouraging entry for new enterprises. For this to work, the ministries must be destroyed. I mean that literally. They must be gotten out of Moscow and out of the way.

What will probably happen and what I hope will happen is that, as the first act of a reform, all state enterprises will be turned over to new bodies, semi-independent of the government, whose job it will be to convert them into joint stock companies. The ministries will, from day one, find that they are out of business.

This must be as open an economy as possible, although here the Soviet Union is much different than Eastern Europe. It is quite possible, in an economy of this size, to increase competition dramatically without opening the borders to foreign competition, simply by unleashing the defense plants and allowing them to compete in the civilian economy under the cover of a devalued exchange rate and a fairly high set of tariffs.

I would add one thing to Nordhaus's table 4 . At the beginning the Soviets need to get a statistical system in place that tells them where they are and where they are going. The system of economic statistics 
they now use is of very uneven quality, but in particular the aggregate statistics are useless. The CIA has done the best it can, and, in fact, if some CIA people were put in Goskomstat (the State Statistics Committee), the Soviets would be better off than they are now. Anything is possible nowadays.

I agree with Nordhaus that a full-bodied complex market will take years to create in the Soviet Union. That does not mean that a fairly simple, rudimentary market cannot be up and operating quickly, say, by the end of 1991, if Soviet leaders work at it. One objection to going this route is that there will be strikes and social unrest, which is undoubtedly true. However, if the government does not do anything this year, there are going to be strikes and social tensions and unrest, but they will be worse.

They will be worse, in part, because the perception is now widespread in the Soviet Union that the government has absolutely no idea what it is doing, which happens to be true. Strikes that come because of government confusion will be a sign of hopelessness, of a lack of any faith in the future. Strikes and protests that come because the reforms are beginning to take hold will be a sign of some hope.

I would also point out that the reform need not be as painful in the Soviet Union as it is in Poland. This is still a country where the net debt is relatively low. It is a country with a gold stock somewhere in the neighborhood of $\$ 35$ billion. It has assets and could use them intelligently if it would get an intelligent reform under way.

Let me conclude by talking about what could happen. The cause of radical reform has gone on a roller coaster since last summer. Leonid Abalkin had a fairly radical proposal, as Nordhaus points out. Prime Minister Nikolai Ryzhkov seemed to torpedo that proposal in December, but, at the same time, Gorbachev did something very interesting. He appointed his first-ever adviser on economics, Nikolai Petrakov, a man whose devotion to markets would make Milton Friedman blush some days. Since January, Petrakov has spent somewhere between one and ten hours a day talking to Gorbachev about economics and putting together an economic program that is going to be coming out in the next few months.

A struggle is going on now that will last for the rest of the year. One set of decrees and laws is now on track in a process that involves Nordhaus through his discussions with people from the Abalkin Reform 
Commission. A somewhat separate, and more radical, operation is going on between Gorbachev and Petrakov. In addition, Stanislav Shatalin, who is a soulmate to Petrakov in his commitment to markets, has joined the presidential commission.

It looks like what Petrakov is going to sign on to-I think with support from Abalkin-is something like a big bang. We will be hearing, over the next few months, much more talk of a Polish-type solution.

What has happened in Poland so far has made a tremendous impression on Soviet economists, a positive impression for the most part. At least two things are critical to the next few months to give a Polish-type solution a chance to work. One is a new government. Most of the government now in power in the Soviet Union needs to go. Unlike Poland, the current government has absolutely no popular support, and it would be very difficult to introduce a reform of the sort they are talking about without that popular support. A new government with many new faces will be critical to the success of a reform. Second, there must be a much more permissive policy than so far on republican autonomy, transforming it from a threat to an opportunity. I do not think this outcome is excluded, as tense as the situation may appear at the moment, particularly with Lithuania.

Even in the best of circumstances, if a radical reform is announced and implemented sometime in 1991, economic performance in the Soviet Union will continue to deteriorate this year and next year because of the inertia built into this system. What we are arguing about now is the end of 1991 on: 1992 and 1993. I think at least some of the Soviet economists are realistic enough to understand this.

\section{General Discussion}

Janos Kornai asserted that political roadblocks are the primary obstacle to reform in the Soviet Union. He observed that the main difference between the Soviet Union and Eastern Europe is the political environment. Eastern Europe is on the way to genuine multiparty systems with populations and governments committed to abandoning socialism. The Soviet government appears committed to revitalization rather than abandonment. To Kornai, the difficulty stems from the intransigence of the entire system, not just the leadership. For this 
reason, whatever influence one or the other economic adviser might have on Gorbachev is less important than Ed Hewett suggested. In Kornai's view, the resistance to a market economy is so widespread throughout the party apparatus that even a leadership unambiguously committed to free markets would find them nearly impossible to achieve. While agreeing that Gorbachev faces great political difficulties, Hewett noted that the party itself is losing power, both from local elections and from attacks by Gorbachev himself.

Hendrik Houthakker contrasted the Soviet Union, where attempts at economic reform have been directed largely from the center, with China during the 1980s, where successful reforms were often regional and involved relinquishing central authority to local agents. In particular he cited the agricultural reforms in Szechwan province and the opening of Canton to foreign investment. The Soviets, by contrast, have resisted attempts such as Lithuania's to become a more open and independent economy. Houthakker asserted that the Soviet population's inexperience with markets is less of an obstacle to reform than frequently claimed, noting that many individuals in the Soviet Union and Eastern Europe have experience in unofficial or underground economies, some with cooperatives. Nordhaus accepted China as a counterexample to the proposition that no socialist country has had a successful reform but questioned its relevance, noting that the agricultural reforms were a onetime catch-up from levels of productivity far below those of Eastern Europe.

Some panelists discussed the role of privatization. William Poole found it crucial both to promote efficiency and to reduce the monetary overhang through the selling of assets, and emphasized that it should be at the top of the list of reforms. Peter Kenen noted that, while privatization in the West has mostly involved the sale of profitable enterprises, the Abalkin report advocates the sale of failed enterprises. He doubted that much overhang could be absorbed by selling such assets.

Kenen stressed the importance of opening the Soviet economy to the rest of the world. Freer trade would allow imported goods to smooth over glitches in the reform process and provide competition. Even more important, an open economy would import a set of internally consistent market prices to the Soviet economy. 


\section{References}

Abalkin Report. 1989. See Radical Reform.

Aganbegyan, Abel. 1988. The Economic Challenge of Perestroika, translated by Pauline M. Tiffin. Bloomington, Ind.: Indiana University Press.

Aven, Peter O. 1990. "The Soviet Tax System: Heritage from the Past and Blueprint for the Future." Working Paper. Laxenburg, Austria: International Institute for Applied Systems Analysis.

Baily, Martin Neil, and Robert J. Gordon. 1988. "The Productivity Slowdown, Measurement Issues, and the Explosion of Computer Power." BPEA, $2: 1988,347-420$.

Central Intelligence Agency. 1988. The World Factbook, 1988. CPAS WF 88001. Washington (May).

Kagalovsky, K., and A. Khandruyev. 1990. "Economic Stabilization: Monetary and Fiscal Policy." Paper presented at a conference on Economic Reform and Integration, International Institute for Applied Systems Analysis. Laxenburg, Austria (March).

Kramer, Jane. 1990. "Letter from Europe." New Yorker, March 12, 1990, pp. 74-90.

Kravis, Irving B., Alan Heston, and Robert Summers. 1982. World Product and Income: International Comparisons of Real Gross Product. Baltimore: Johns Hopkins Press for the World Bank.

Kurtzweg, Laurie. 1987. "Trends in Soviet Gross National Product." In Gorbachev's Economic Plans, vol. 1. Study Papers Submitted to the Joint Economic Committee. 100 Cong. 1 sess. Washington: GPO.

Levine, Herbert S. 1982. "Possible Causes of the Deterioration of Soviet Productivity Growth in the Period 1976-1980." In Soviet Economy in the 1980s: Problems and Prospects, Part 1. Selected Papers Submitted to the Joint Economic Committee. 97 Cong. 2 sess. Washington: GPO.

Maddison, Angus. 1989. The World Economy in the 20th Century. Paris: Development Centre of the OECD.

Ofer, Gur. 1990. "Macroeconomic Issues of Soviet Reforms." Paper presented to the Fifth Annual Conference on Macroeconomics, National Bureau of Economic Reforms. Cambridge, Mass. (March).

Okun, Arthur M. 1973. "Upward Mobility in a High-Pressure Economy." BPEA, 1:1973, 207-61.

Radical Reform. 1989. Radical Economic Reform: Top-Priority and LongTerm Measures. Study presented by Leonid I. Abalkin, Deputy Prime Minister, to the Organizing Committee of the All-Union Conference and Workshop on the Problems of Radical Economic Reform (November). English translation in mimeo.

Ranis, Gustav. 1990. "Global Perestroika." Yale University.

Shmelev, Nikolay P. 1988. "Rethinking Price Reform in the U.S.S.R." Soviet Economy 4 (October-December): 319-27. 
Stigler, George J., and James K. Kindahl. 1970. The Behavior of Industrial Prices. No. 90, General Series. Cambridge, Mass.: National Bureau of Economic Research.

Summers, Robert, and Alan Heston. 1988. "A New Set of International Comparisons of Real Product and Price Levels Estimates for 130 Countries, 1950-1985." Review of Income and Wealth, Series 34 (March): 1-25.

Treml, Vladimir G. 1988. "Perestroika and Soviet Statistics." Soviet Economy 4 (January-March): 65-94.

Wallich, Henry C. 1955. Mainsprings of the German Revival. New Haven: Yale University Press.

World Bank. 1989. World Development Report, 1989. Washington: Published for the World Bank by Oxford University Press.

Yasin, Yevgeniy. 1990. "Modern Market Institutions and Problems of Economic Reform in the U.S.S.R." Paper presented to a conference on Economic Reform and Integration, International Institute for Applied Systems Analysis. Laxenburg, Austria (March).

Yeltsin, Boris. 1990. Against the Grain, translated by Michael Glenny. New York: Summit. 